\title{
PERANAN KEUCHIK TERHADAP KELANCARAN ADMINISTRASI GAMPONG MENURUT QANUN NOMOR 5 TAHUN 2003 TENTANG PEMERINTAH GAMPONG
}

\author{
${ }^{1}$ Armiwal, ${ }^{2}$ Suhaibah \\ ${ }^{1}$ Program Studi Ilmu Sosial Politik Fakultas Sosial Politik Universitas Iskandarmuda \\ ${ }^{2}$ Program Studi Ilmu Hukum Fakultas Hukum Universitas Jabal Ghafur
}

\begin{abstract}
ABSTRAK
Provinsi Aceh merupakan satuan pemerintah daerah yang diberi status oleh pemerintah pusat otonomi khusus (lex spesialis), yang selanjutnya diatur dengan Undang-Undang Nomor 11 Tahun 2006 tentang pemerintahan Aceh. Tentu kewenangan serta pengelolaan pemerintahanya berbeda jika dibandingkan dengan provinsi lain di Indonesia, hal tersebut jelas terimplementasi dalam Undang-Undang Nomor 44 Tahun 1999 tentang keistimewaan Aceh. Adanya Qanun Pemerintahan Gampong Nomor 5 Tahun 2003 di Gampong merupakan salah satu dimensi penting dalam rangka mewujudkan cita-cita demokratisasi dan reformasi pemerintahan yang di dalamnya juga mengatur mengenai Pemerintahan Gampong. Dengan adanya perangkat hukum tersebut telah membuka peluang bagi terwujudnya demokratisasi sampai pada tingkat pedesaan melalui perubahan konfigurasi pemerintahan desa sebagai institusi perwakilan rakyat di tingkat gampong yang mempunyai kedudukan sejajar dan menjadi mitra pemerintah gampong. Pemerintah gampong merupakan penyelenggaraan pemerintahan yang dilaksanakan oleh pemerintah gampong dan tuha peuet gampong. pemerintah gampong terdiri dari kepala gampong dan perangkat gampong. perangkat gampong bertugas membantu kinerja kepala gampong dalam melaksanakan tugas-tugas dan fungsi-fungsi pemerintah gampong. perangkat gampong terdiri dari sekretaris gampong dan perangkat gampong lainnya. bersama perangkat gampong, kepala gampong sebagai pimpinan struktur pemerintah desa memiliki peranan yang signifikan dalam pengelolaan proses sosial dalam masyarakat gampong (Qanun Pemerintahan Gampong Nomor 5 tahun 2003). Keuchik sesuai dengan kedudukannya sebagai pimpinan dalam sebuah Gampong bertugas untuk menyelenggarakan urusan rumah tangganya sendiri, menjalankan urusan pemerintah, pembangunan dan pembinaan masyarakat, serta mengarahkan masyarakatnya kepada usaha-usaha untuk memperlancar pelaksanaan kegiatan pemerintahan dan pembangunan Gampong. Keberhasilan penyelenggaraan pemerintahan gampong juga sangat dipengaruhi oleh kemampuan untuk melaksanakan administrasi Gampong dengan baik.
\end{abstract}

Kata Kunci : Peran Keuchik Dalam Administrasi Gampong

\section{PENDAHULUAN}

Provinsi Aceh merupakan satuan pemerintah daerah yang diberi status oleh pemerintah pusat otonomi khusus (lex spesialis), yang selanjutnya diatur dengan Undang-Undang Nomor 11 Tahun 2006 tentang pemerintahan Aceh. Tentu kewenangan serta pengelolaan pemerintahanya berbeda jika dibandingkan dengan provinsi lain di Indonesia, hal tersebut jelas terimplementasi dalam Undang-Undang Nomor 44 Tahun 1999 tentang keistimewaan Aceh. Dalam rangka pelaksanaan Otonomi Khusus Bagi Provinsi Daerah Istimewa Aceh sebagai Provinsi Aceh, maka perlu pengaturan tentang Susunan, Kedudukan dan Kewenangan Pemerintahan Gampong dalam Provinsi Aceh. Dengan berlakunya otonomi khusus tersebut, maka diperlukan penataan, kembali tugas, fungsi dan wewenang Pemerintah Gampong dalam penyelenggaraan pemerintahan dan peningkatan pelaksanaan Syariat Islam serta, pengembangan adat dan 
adat istiadat sebagaimana dalam Qanun Pemerintahan Gampong Nomor 5 tahun 2003.

Adanya Qanun Pemerintahan Gampong Nomor 5 Tahun 2003 di Gampong merupakan salah satu dimensi penting dalam rangka mewujudkan cita-cita demokratisasi dan reformasi pemerintahan yang di dalamnya juga mengatur mengenai Pemerintahan Gampong. Dengan adanya perangkat hukum tersebut telah membuka peluang bagi terwujudnya demokratisasi sampai pada tingkat pedesaan melalui perubahan konfigurasi pemerintahan desa sebagai institusi perwakilan rakyat di tingkat gampong yang mempunyai kedudukan sejajar dan menjadi mitra pemerintah gampong.

Pemerintah gampong merupakan penyelenggaraan pemerintahan yang dilaksanakan oleh pemerintah gampong dan tuha peuet gampong. pemerintah gampong terdiri dari kepala gampong dan perangkat gampong. perangkat gampong bertugas membantu kinerja kepala gampong dalam melaksanakan tugas-tugas dan fungsi-fungsi pemerintah gampong. perangkat gampong terdiri dari sekretaris gampong dan perangkat gampong lainnya. bersama perangkat gampong, kepala gampong sebagai pimpinan struktur pemerintah desa memiliki peranan yang signifikan dalam pengelolaan proses sosial dalam masyarakat gampong (Qanun Pemerintahan Gampong Nomor 5 tahun 2003).

Gampong mempunyai tugas menyelenggarakan pemerintahan, melaksanakan pembangunan, membina masyarakat dan meningkatkan pelaksanaan Syari'at Islam. Untuk melaksanakan tugas sebagaimana yang telah ditetapkan, gampong mempunyai fungsi sebagai penyelenggaraan pemerintahan, baik berdasarkan asas desentralisasi, dekonsentrasi dan urusan tugas pembantuan serta segala urusan pemerintahan lainnya yang berada di gampong, pelaksanaan pembangunan, baik pembangunan fisik dan pelestarian lingkungan hidup maupun pembangunan mental spiritual di gampong, pembinaan kemasyarakatan di bidang pendidikan, peradatan, sosial budaya, ketentraman dan ketertiban masyarakat di gampong, peningkatan pelaksanaan Syari'at Islam, peningkatkan percepatan pelayanan kepada masyarakat, dan penyelesaian persengketaan hukum dalam hal adanya persengketaan-persengketaan atau perkaraperkara adat dan adat istiadat di gampong.

Keistimewaan yang dimaksud di sini adalah pelaksanaan dan pemberlakuan syariat Islam secara kaffah, kemudian pada aspek pelaksanaan pendidikan, serta penyelenggaraan adat istiadat. Tindak lanjut dari ke Istimewaan tersebut tentu dapat terlihat dalam istilah-istilah serta aplikasi pelaksanaan pemerintahan di Aceh, yaitu tentang pemerintahan gampong dan mukim yang merupakan jenjang hirarki dalam struktur pemerintahan secara umum di Aceh. Keberadaan nama lembaga tersebut sudah ada sejak dulu dan terus dilestarikan, serta dijaga dan dipelihara keberadaannya. Hal ini tentu sebagai bentuk kearifan lokal di Aceh, dalam rangka kelangsungan hidup masyarakat berbangsa dan bernegara dalam bingkai Negara Kesatuan Republik Indonesia yang berlandaskan Pancasila dan Undang-Undang Dasar 1945. Negara tetap mengakui dan menghormati kesatuankesatuan masyarakat hukum adat, beserta hak tradisionalnya sepanjang masih hidup dan sesuai dengan perkembangan masyarakat dan prinsip negara kesatuan Republik Indonesia, hal itu dijelaskan dalam konstitusi Undang-Undang Dasar 1945. Selanjutnya menurut penjelasan Qanun Nomor 5 Tahun 2003 tentang Pemerintahan Gampong, yang dimaksud dengan gampong adalah kesatuan masyarakat hukum yang mempunyai organisasi pemerintahan terendah langsung berada di bawah mukim, yang menempati wilayah tertentu, yang dipimpin oleh seorang keuchik, berhak menyelenggarakan urusan rumah tangganya sendiri.

Pada pasal 2 dan 3 Qanun Nomor 5 Tahun 2003 tentang Pemerintahan Gampong, bahwa gampong merupakan organisasi pemerintahan terendah yang 
berada di bawah mukim dalam struktur organisasi pemerintahan di Provinsi Aceh. Gampong berfungsi serta diberikan kewenangan untuk menyelenggarakan pemerintahan, melaksanakan pembangunan, membina masyarakat dan meningkatkan pelaksanaan syariat Islam, sebagaimana yang telah diamanahkan dalam ketentuan perundang-undangan, khususnya di Aceh. Penyelenggaraan pemerintahan gampong tidak terlepas dari peran Keuchik sebagai menjadi hakim perdamaian antar penduduk dalam gampong. Segala sesuatu yang berhubungan dengan kegiatan pemerintahan harus mendapat persetujuan dari Keuchik dan Tuha Peut gampong.

Namun kenyataan masih banyak Keuchik yang belum mampu menyelesaikan masalah yang dihadapi oleh masyarakat pada umumnya meskipun sudah dibantu oleh tuha peuet.

\section{KERANGKA PEMIKIRAN DAN TINJAUAN KEPUSTAKAAN}

Menurut Qanun Nomor 5 Tahun 2003 tentang Pemerintahan Gampong menjelaskan, yang dimaksud dengan gampong adalah kesatuan masyarakat hukum yang mempunyai organisasi pemerintahan terendah dan langsung berada di bawah Mukim, atau nama lain yang memiliki wilayah tertentu, yang dipimpin oleh seorang Keuchik dan berhak menyelenggarakan urusan rumah tangganya sendiri. Kemudian pada defenisi lain disebutkan gampong adalah kesatuan masyarakat hukum yang berda dibawah Mukim dan di pimpin oleh seorang keuchik atau nama lain yang berhak menyelenggarakan urusan rumah tangga sendiri. (Peraturan Gubernur Aceh Nomor 25 Tahun 2011, tentang pedoman Umum Penyelenggaraan Pemerintah Gampong). Sedangkan dalam Undang-Undang Nomor 32 Tahun 2004 tentang Pemerintahan Daerah, desa atau gampong adalah kesatuan masyarakat hukum yang memiliki batasbatas setempat, bedasarkan asal usul dan adat istiadat setempat, yang diakui dan dibentuk dalam sistem pemerintahan nasional, dan berada di kabupaten dan kota, sebagaimana dimaksud dalam UUD Negara Republik Indonesia Tahun 1945. Memang agak sulit sedikit menentukan defenisi tunggal mengenai perdesaan atau gampong, apalagi konteks kekinian menunjukan perbedaan kota dan desa tidak lagi setajam masa awal serta pra modernisasi, dari sisi ekonomi misalnya tidak sedikit warga desa atau gampong yang tak lagi bertumpu pada sektor pertanian begitu juga dalam sisi interkasi sosial. Selanjutnya pada pengertian lain disebutkan bahwa yang dimaksud dengan desa atau gampong adalah tempat yang berpenghuni kurang dari dua ribu lima ratus orang, begitupun sebaliknya. Untuk keperluan analisis psikologi sosial, desa merupakan tempat yang memiliki tempat keakraban yang tinggi serta informalitas menandai hubungan antar anggotanya.

\section{Pemerintah Gampong \\ Kedudukan Pemerintah Gampong}

Pemerintah gampong berkedudukan sebagai unsur penyelenggara pemerintahan gampong, bersama-sama dengan tuha peut gampong, menyelenggarakan urusan pemerintahan yang menjadi kewenangan gampong. Pemerintah gampong terdiri atas keuchik dan badan permusyawaratan gampong yang disebut tuha peut, atau nama lain. Dalam melaksanakan tugasnya kechik dibantu perangkat gampong yang terdiri atas sekretaris gampong dan perangkat gampong lainnya (Peraturan Gubernur Aceh 25 Tahun 2011).

Selanjutnya di Pasal 11 Qanun Nomor 5 tahun 2003 dijelaskan pula bahwa keuchik adalah kepala badan eksekutif gampong dalam penyelenggaraan pemerintahan gampong, dengan sistem pemerintahan gampong, sistem demokrasi dari bawah (bottom-up) benar-benar dapat dilaksanakan. Dalam pemerintahan gampong, bidang eksekutif gampong dilaksanakan oleh keuchik dan Teungku Imuem Meunasah dengan urusan yang berbeda. Di gampong, pimpinan keagamaan adalah Teungku Imuem Meunasah (Sulaiman Tripa, 2003) 


\section{Perangkat Gampong}

Perangkat desa atau gampong, terdiri dari sekretaris dan perangkat lainnya. Sekretaris desa atau gampong di isi dari pegawai negeri sipil yang memenuhi persyaratan. Sementara itu, sekretaris desa yang sudah ada sebelum berlaku UndangUndang Nomor 32 Tahun 2004 tentang Pemerintahan Gampong, di isi oleh bukan dari pegawai negeri sipil, namun secara bertahap akan diangkat menjadi pegawai negeri sipil sesuai dengan peraturan perundang-undangan yang berlaku (Abdullah, 2005: h. 13)

Dalam Peraturan Gubernur Nomor 25 Tahun 2011 tentang Pedoman Umum Penyelenggaraan Pemerintah Gampong, perangkat gampong berkedudukan sebagai unsur pembantu dan bertangung jawab kepada keuchik. Dalam melaksanakan tugasnya keuchik dibantu oleh perangkat gampong yang terdiri dari sekretariat gampong, pelaksana teknis dilapangan dan unsur kewilayahan. Perangkat gampong terdiri dari :

1) Sekretaris gampong berkedudukan sebagai unsur staf, memimpin sekretariat gampong untuk membantu keuchik dalam rangka menjalankan pemerintahan gampong.

2) Unsur staf sekretariat gampong, penataan unsur staf sekretariat gampong harus mencerminkan katagori fungsi staf dalam mengelola adminitrasi pemerintahan gampong, sehinga nomen klatur yang dapat digunakan adalah "kepala urusan", namun dapat pula menggunakan nomen klatur lain sesuai sistem nilai adat istiadat.

\section{Bentuk dan Susunan Pemerintahan Gampong}

Dalam Qanun Nomor 5 Tahun 2003 tentang pemerintahan gampong, pada Bab IV, tentang bentuk dan susunan pemerintahan gampong, pasal 9 dijelaskan bahwa, di gampong dibentuk pemerintahan gampong dan Tuha Peut gampong yang secara bersama-sama menyelenggarakan pemerintahan gampong. Kemudian selanjutnya pada pasal 10 dijelaskan lagi pemerintahan gampong terdiri dari Imuem Meunasah beserta perangkat gampong lainnya.

Kemudian pada pasal 11 Qanun Nomor 5 tahun 2003 tentang pemerintahan gampong dijelaskan pula bahwa Keuchik adalah Kepala Badan Eksekutif Gampong dalam penyelenggaraan pemerintahan gampong. Dengan sistem pemerintahan gampong yaitu sistem demokrasi dari bawah (bottom-up) benar-benar dapat dilaksanakan. Dalam pelaksanaan pemerintahan gampong, bidang eksekutif gampong dilaksanakan oleh Keuchik dan Teungku Imuem Meunasah dengan urusan yang berbeda pula. Sedangkan yang melaksanakan aspek keagamaan adalah Teungku Imuem Meunasah (Sulaiman Tripa, 2003: h. 60).

Kemudian posisi Imuem Meunasah setara atau setingkat dengan Keuchik walau pun masing-masing memiliki urusan yang berbeda, begitu juga dengan bidang legislatif, dalam gampong secara tegas dibatasi bahwa unsur legislatif adalah di luar badan eksekutif.

Kemudian konsep pemerintahan gampong, struktur kepemimpinannya terdiri dari atas keuchik, tuha peut dan teungku Imum atau teungku sagoe, dalam perkembangan dinamika kehidupan masyarakat dan tata pemerintahan, akibat modernisasi dan globalisasi, maka pada masing-masing unit tersebut dibentuk Sekretaris gampong yang kemudian lebih disempurnakan menjalankan berbagai urusan pemerintahan. Salah satu perangkat kelembagaan struktur gampong adalah tuha peut, tuha peut sebagai sub perangkat kelembagaan gampong, memiliki makna, fungsi, peran dan kewenangan tersendiri untuk memperkuat fungsi dan tugas kewenangan keuchik dalam menjalankan tugas pokok dan fungsi selaku pemimpin gampong. Keuchik adalah pemimpin atau "ku/ bapak" gampong, sedangkan teungku diibaratkan sebagai "ma/Ibu" atau kaitan adat dan agama (Ismail, 2009: h. 67).

Keuchik sebagai pemimpin gampong dari aspek kultur keacehan pada dirinya 
melengkat fungsi "mono trias functions "artinya tiga fungsi kekuasaan dalam ketunggalan, yaitu fungsi eksekutif, legislatif dan yudukatif, dengan tugas pokok" keureuja hudeip, keureuja mate". Keuchik dalam menjalankan tugas pokoknya dibantu dan didukung oleh teungku dan ureung tuha/ tuha peut. ureung tuha adalah kaum yang berpengalaman bijaksana dan sopan santun, berpengetahuan adat dalam satu gampong (boleh tua atau muda). Jumalah anggota dewan orang tua tidak tentu dan diangkat atas kesepakatan bersama(tidak dipilih dan boleh secara diam-diam). Demikian dari aspek budaya adat tentang struktur gampong (Ismail, 2009: h. 56).

Kemudian pada Pasal 1 Ayat 7 Qanun Nomor 5 tahun 2003 yang menyebutkan bahwa tuha peuet gampong atau nama lain adalah badan perwakilan ampong yang terdiri dari unsur ulama, tokoh adat, pemuka masyarakat dan cerdik pandai yang ada di gampong. Jadi, tuha peut gampong biasanya dipilih dari berbagai unsur. Unsur pemerintahan diambil biasanya orang yang sudah menjabat sebagai keuchik atau orang yang sudah pernah terlibat dalam pemerintahan gampong. Demikian halnya dengan pertanggungjawaban. Dalam kepemimpinan Keuchik, pertanggungjawaban dilakukan kepada masyarakat. Dalam kenyataan, biasanya hal itu dilaksanakan melalui tuha peut.

\section{Peran Keuchik Dalam Pemerintahan Gampong}

Keucik adalah nama untuk pemimpin gampong didaerah aceh, keucik juga merupakan pimpinan eksekutif dari pemerintahan gampong. Menurut peraturan pemerintah nomor 43 tahun 2004 masa jabatan keucik adalah 6 tahun dapat diperpanjangkan lagi untuk tiga kali masa jabatan berikutnya.

Berdasarkan Undang-Undang Pemerintah Aceh Nomor 11 Tahun 2006 tentang Pemerintahan Aceh, disebutkan bahwa gampong dipimpin oleh seorang keucik yang dipilih secara langsung oleh masyarakat untuk masa jabatan 6 tahun dan dapat dipilih kembali hanya satu kali masa jabatan berikutnya. dalam melaksanakan tugasnya keucik dibantu perangkat gampong yang terdiri dari sekretaris gampong dan perangkat gampong lainnya. Dalam melaksanakan tugasnya sekretaris gampong dan perangkat gampong lainnya bertanggung jawab kepada keucik.

Keuchik tidak bertanggung jawab kepada Camat, namun hanya dikoordinasikan saja oleh Camat. Keuchik dilarang menjadi pengurus partai politik (namun boleh menjadi anggota partai politik), merangkap jabatan sebagai Ketua atau Anggota BPD (tuha peut), dan lembaga kemasyarakatan, merangkap jabatan sebagai Anggota DPRD, terlibat dalam kampanye Pemilihan Umum, Pemilihan Presiden, dan Pemilihan Kepala Daerah. Keuchik dipilih langsung melalui Pemilihan Kepala Desa (Pilkades) oleh penduduk gampong setempat ataupun melalaui duek pakat atau musyawarah. Usia, SLTP, serta merupakan penduduk gampong setempat. Penyelenggaraan Pemilihan keuchik dilakukan oleh Panitia Pemilihan, dimana dibentuk oleh tuha peut, dan anggotanya terdiri dari unsur perangkat gampong, dan tokoh masyarakat.

\section{Peran dan Tugas Keuchik}

Keuchik sesuai dengan kedudukannya sebagai pimpinan dalam sebuah Gampong bertugas untuk menyelenggarakan urusan rumah tangganya sendiri, menjalankan urusan pemerintah, pembangunan dan pembinaan masyarakat, serta mengarahkan masyarakatnya kepada usaha-usaha untuk memperlancar pelaksanaan kegiatan pemerintahan dan pembangunan Gampong. Keberhasilan penyelenggaraan pemerintahan gampong juga sangat dipengaruhi oleh kaemampuan untuk melaksanakan administrasi Gampong dengan baik. Hal ini karena sekarang banyak Gampong yang administrasi gampongnya masih kurang baik. Padahal mengenai penyelenggaraan pemerintahan gampong, Pemerintah Aceh telah mengeluarkan Qanun Nomor 5 Tahun 2003 Tentang Pemerintahan Gampong yang 
dapat dijadikan pedoman dalam penyelenggaraan pemerintahan di gampong.

Lebih lanjut Qanun Nomor 5 Tahun 2003 tentang pemerintahan Gampong menyatakan bahwa, Geuchik menjadi hakim perdamaian antar penduduk dalam Gampong, Pasal 14 ayat (2) menjelaskan tentang Geuchik sebagai hakim perdamaian sebagaimana yang dimaksud pada ayat (1) huruf f pasal 14 diatas yang dibantu oleh Imuem Meunasah dan Tuha Peut Gampong. Oleh karena itu dalam melaksanakan tugas dan kewajibannya sebagaimana tersebut diatas, Geuchik wajib bersikap adil, tegas, arif dan bijaksana.

Kendatipun Qanun No. 5 tahun 2003 telah mengatur sedemikian penting mengenai kedudukan dan fungsi Geuchik, namun pada kenyataannya fungsi dan tugas Geuchik belum berjalan sebagaimana seharusnya seperti halnya tugas Keuchik sebagai hakim perdamaian antar penduduk, memajukan perekonomian masyarakat dan memelihara kelestarian lingkungan hidup.

\section{Peranan Keuchik terhadap Kelancaran Administrasi Gampong Menurut Qanun Nomor 5 Tahun 2003 tentang Pemerintah Gampong}

Penataan kehidupan masyarakat maupun pemerintahan, masing-masing gampong telah memilih tuha peut selaku pemerintahan gampong untuk menjalankan roda pemerintahan dalam sebuah gampong. Masing-masing pemerintahan gampong sudah diatur tugas, fungsi dan wewenangnya, namun dalam penyelenggaraan pemerintahan gampong ada hal-hal yang tidak sesuai dengan yang diamanatkan Qanun Nomor 5 Tahun 2003 tentang Pemerintahan Gampong, terutama menyangkut tugas dan fungsi keuchik dan Tuha Peut, sehingga hubungan fungsional yang terjalin tidak maksimal.

Meski kedua lembaga ini punya kelorasi yang lebih erat dalam menjalankan roda pemerintahan gampong akan tetapi peranan keuchik lebih dominan karena banyak kebijakan dan keputusan yang langsung diputuskan tanpa meminta persetujuan dari tuha peut. Misalnya dalam hal melaksanakan pembangunan gampong, sebenarnya keuchik terlebih dahulu harus mengadakan musyawarah dengan anggota Tuha Peut, begitu juga dengan proses perencanaan dan pelaksanaan pembangunan gunan gampong.

Hal ini jelaskan bahwa keuchik lebih besar perannya dalam penyelenggaraan pemerintahan gampong, meski lembaga tuha peut memiliki tugas dan fungsi yang telah diamanatkan dalam qanun.

Keuchik dalam berbagai hal terutama memecahkan persoalan gampong, peran Keuchik yang dilakukan tersebut sudah sesuai dengan Qanun Nomor 5 tahun 2003 (tentang pemerintahan gampong). Namun belum semuanya terlaksana sebagaimana dalam qanun, Keuchik secara kelembagaan dan personal punya keterbatasan, terutama menyangkut tingkat pendidikan dan pengalaman yang masih minim.

Keuchik juga membuat reusam tentang pengaturan sawah dan hewan ternak dalam rangka ketertiban sosial masyarakat, menurut keterangan yang diperoleh dari penelitian bahwa belum semuanya masyarakat mau mentaati aturan tersebut, sehingga kadangkadang aturan yang telah dibuat kurang bermakna.

Berdasarkan wawancara di atas, maka dapat dipahami bahwa peran Keuchik secara keseluruhan belum aktif, karena dalam pelaksanaan perannya sebagai Keuchik tidak mengentahui tugas dan fungsi masingmasing sebagaimana yang diamanatkan dalam Qanun Nomor 5 tahun 2003 tentang pemerintahan gampong. Selama pengamatan penulis terhadap Keuchik dalam masyarakat gampong belum difungsikan dengan baik, padahal Keuchik memiliki peran yang besar bagi kemaslahatan masyarakat. Hal tersebut dapat dilihat dari penjelasan dalam Qanun Nomor 5 tahun 2003 tentang pemerintahan gampong. Oleh sebab itu, untuk masa yang akan datang kerjasama serta koordinasi dan berkelanjutan. 


\section{Hambatan Keuchik terhadap Kelancaran Administrasi Gampong Menurut Qanun Nomor 5 Tahun 2003 tentang Pemerintah Gampong}

Keuchik untuk mewujudkan kesejahteraan masyarakat. Kedua lembaga ini saling berkaitan satu sama lain. Di mana keuchik sebagai pelaksana penyelenggaraan pemerintahan dan pembangunan gampong, sedangkan Tuha Peut sebagai wadah perwujudan pelaksanaan demokrasi, keterbukaan dan partisipasi rakyat dan berkedudukan sejajar dan menjadi mitra dari pemerintahan Gampong.

Salah satu hambatan dalam melaksanakan tugas tuha peut adalah masyarakat, karena mengurus orang banyak susah untuk di ajak mengerti tentang keadaan yang ada, sehingga ada beberapa yang telah diputuskan tidak berjalan sebagaimana yang telah diputuskan bersama dengan unsur pemerintahan gampong lainya. Selanjutnya untuk ke depan anggota tuha peut masih sanggup untuk menjalankan tugas sebagaimana yang diharapkan. Kalau ditanyakan masalah tentang Qanun Nomor 5 tahun 2003 tentang pemerintahan gampong, saya tidak tahu tentang qanun tersebut.

Dalam melaksanakan perannya, tuha peut mendapatkan kendala berupa kurangnya pemahaman mereka mengenai tugas dan tanggung jawab sebagai perangkat gampong. Misalnya peran tuha peut sebagai badan perwakilan masyarakat dalam melaksanakan pembangunan gampong bersama dengan unsur pemerintahan gampong lainnya kurang memahami apa tugas yang harus dilaksanakan dalam pembangunan gampong. Selain tugas-tugas utama sebagaimana dalam qanun, tuha peut juga ikut berpatisipasi dalam menyelesaikan persoalan-persoalan masyarakat melalui pendekatan sosial dan adat, dengan mendamaikan kedua belah pihak yang bersengketa.

Berdasarkan keterangan yang diperoleh dari informan bahwa selama menjabat sebagai Keuchik mendapat hambatan dalam menjalan tugasnya, masalah pro kontra setuju dan tidak setuju, biasa dalam kehidupan berdemokrasi. Kemudian masalah Qanun yang mengatur tentang pemerintahan gampong juga kurang dipahami. Kesanggupanya untuk melaksanakan peran sebagai Keuchik untuk masa yang akan datang, jika sekiranya dipercaya lagi, untuk menempati posisi anggota tuha peut.

\section{PENUTUP}

\section{A.Kesimpulan}

1. Peranan Keuchik terhadap kelancaran administrasi Gampong menurut Qanun Nomor 5 Tahun 2003 tentang Pemerintah Gampong bahwa Keuchik sebagai hakim perdamaian sebagaimana yang dimaksud pada ayat (1) huruf f pasal 14 diatas yang dibantu oleh Imuem Meunasah dan Tuha Peut Gampong. Oleh karena itu dalam melaksanakan tugas dan kewajibannya sebagaimana tersebut diatas, Geuchik wajib bersikap adil, tegas, arif dan bijaksana.

2. Hambatan Keuchik terhadap kelancaran administrasi Gampong menurut Qanun Nomor 5 Tahun 2003 tentang Pemerintah Gampong secara keseluruhan kurang efektif melaksanakan perannya sebagai perangkat pemerintahan di Gampong sebagaimana yang diamanatkan dalam Qanun Nomor 5 Tahun 2003 Tentang pemerintahan Gampong. Hal ini karena Keuchik kurang memahami tugas dan fungsi sebagaimana yang diuraikan di dalam Qanun tersebut serta dipengaruhi oleh tingkat pendidikan yang rendah, sehingga Keuchik kurang efektif dalam melaksanakan perannya sebagai perangkat pemerintahan gampong dan masih tidak dapat dijalankan dengan afektif sebagaimana yang diatur dalam Qanun Nomor 5 Tahun 2003 Tentang pemerintahan Gampong. Pelaksanaan peran Tuha Peut sebagaimana yang diamanatkan dalam Qanun tersebut ternyata belum terealisasi dengan baik, hal ini karena tingkat pendidikan dan pemahaman mengenai pelaksanaan tugas 
dan tanggung jawab sebagai Keuchiek masih rendah.

\section{Saran}

1. Selama ini kita melihat Peran Keuchik kurang efektif dalam menjalankan fungsinya, padahal lembaga ini memiliki pengaruh yang besar bagi kemaslahatan masyarakat. Indikator ini tidak terlepas dari faktor yang paling dominan adalah pengaruh dari tentang Qanun Nomor 5 Tahun 2003 tentang pemerintahan Gampong. Oleh sebab itu sebaiknya kerjasama serta koordinasi yang baik antara pemerintah dan lembaga adat tuha peut merupakan sebuah kemutlakan yang harus dijalin.

2.Peran dan fungsi lembaga tuha peut sebaiknya perlu dikembangkan dan diberikan apresiasi dengan memberikan dukungan moril dan material oleh pemerintah. Ketika lembaga adat gampong di Aceh berfungsi dengan baik maka masyarakat akan hidup damai penuh dengan keakraban antara mereka sebagaimana diamanatkan dalam UUPA dan MoU Helsinki beberapa tahun yang yang lalu. Kedamaian dan kesajahteraan masyarakat merupakan dambaan semua kita. Pemerintah dalam satu sisi, dan masyarakat di sisi lain. Untuk meningkatkan kepercayaan Keuchiek, sebaiknya perlu melaksanakan Pelatihan kepada Keuchik.

\section{DAFTAR PUSTAKA}

Ismail.2009. Lembaga Tuha Peut : Fungsi dan Peran Menyahuti Tantangan Zaman. Jurnal, Fak.Hukum Unsyiah. Banda Aceh.

M. Juned, T.2003. Menuju Revitalisasi Hukum dan Adat Aceh, Yayasan Rumpun Bambu dan CSSP, Jakarta.
M. Said, 2001. Aceh Sepanjang Abad, Waspada, Medan

M. Puteh, Jakfar. 2012. Sistem Sosial Budaya dan Adat Masyarakat Aceh. Grafindo Litera Media. Jakarta.

Nawawi, Hadari, 1991, Metode Penelitian Bidang Sosial, Gajah Mada University Press, Yogyakarta.

Sulaiman Tripa. 2009. Prospek dan Tantangan Pemerintahan Gampong di Nanggroe Aceh Darussalam, Jurnal Media Hukum. Banda Aceh.

Soehartono, Irawan. 2008. Metode Penelitian Sosial. PT. Remaja Rosdakarya : Bandung.

Taqwaddin. 2009. Gampong Sebagai Basis Perdamaian Di Aceh, Makalah, Banda Aceh.

Tri Utama, Eko. 2007. Peranan Badan Permusyaratan Desa Dalam Perencanaan Pembangunan Desa (Suatu Studi Deskriptif Tentang Proyek Desa Melalui APBD di Desa Sampali Kecamatan Percut Sei Tuan), Skripsi Fakultas Ilmu Sosial dan Ilmu Politik, Universitas Sumatra Utara. Medan.

Qanun Pemerintahan Gampong Nomor 5 Tahun 2005.

Aceh Qanun No. 9 Tahun 2008 tentang Pembinaan Kehidupan Adat Istiadat Undang-undang Perintah Aceh Nomor 11 Tahun 2006. Jakarta.

Peraturan Gubernur No. 25 Tahun 2011 (tentang Pedoman Umum Penyelenggaraan Pemerintah Gampong. 